\title{
Management of the Career Guidance Process at the University
}

\author{
Safargaliev E.R. \\ University of Management "TISBI" \\ Russian State University of Justice \\ Kazan, Russia \\ 927242@mail.ru
}

\author{
Zinurova G.Kh. \\ University of Management "TISBI" \\ Russian State University of Justice \\ Kazan, Russia \\ gzinurova80@mail.ru
}

\author{
Safargalieva D.F. \\ University of Management "TISBI" \\ Russian State University of Justice \\ Kazan, Russia \\ sineke.sdf@mail.ru
}

\begin{abstract}
The article reveals the problems of professional orientation in modern school. For Russian high school students, the choice of future profession is closely related to the choice of the unified state exam. Choosing the exam, the student is determined with his specialty in the University, which means that he must already have an idea about a certain profession. As a method of assessing the effectiveness of career guidance, a survey was used, which was conducted in February 2019 among schoolchildren of Mendeleev municipal district. The article presents the answers of respondents on such issues as the decision of students to choose their future profession, examines the profession that students have chosen Mendeleev municipal district of the Russian Federation Republic of Tatarstan, identifies the factors that influenced the choice of future profession. Currently, many organizations are engaged in career guidance work, meaning networking. With this approach, there is interaction with the maximum possible number of links and inclusion of any number of objects, work is carried out on a variety of uncoordinated projects. In Russia, dozens of sociological studies are regularly conducted, the results of which reflect that school graduates have a poor understanding of their opportunities, requirements for the profession and the labor market. In connection with the current situation, a model of creating a career guidance laboratory at the University is proposed, which unites all participants of the chain: schoolcollege-university-employer, etc.
\end{abstract}

Keywords-management of vocational guidance; vocational guidance of students; choice of profession; regular and extracurricular activities of the school; vocational guidance laboratory; networking.

\section{INTRODUCTION}

In 1903, the first career guidance office was opened in France. In 1908, a Bureau appeared in Boston, the main purpose of which was to assist teenagers in choosing a future profession. The main reason for the emergence of career guidance is due to the fact that it was at this time that a significant number of people in these countries faced the problem of choice freedom, which was not there before.

At the same time in Russia in 1871 the book of K. K. Weber "Stories about factories and plants" was published, which gave young people an idea of the existing professions [1]. In 1922 in RSFSR created Bureau on choice professions for teenagers. Initially, career guidance was considered from the point of view of human resources optimal use and their distribution in various activities in the interests of production.

Currently, vocational guidance is understood as helping to choose the direction of study, training and career management. Conducting career guidance work among schoolchildren allows to solve acute social problems in society related to job search, employment, justification of their opportunities during an interview with an employer, etc. Therefore, to take place in the life and professional self-determination of schoolchildren, it is necessary to carry out career guidance support of the personal, value, life self-affirmation [2, 3]. Self-determined person can realize his inclinations and abilities to a particular area of work as a prerequisite for the realization of a career.

For Russian high school students, the choice of future profession is closely related to the choice of the unified state exam. Choosing the exam, the student is determined with his specialty in the University, which means that he must already have an idea about a certain profession.

Thus, many high school students, who are faced with the task of choosing a profession, do not have adequate ideas about modern professions and the system of vocational training. Many students can not conduct self-assessment, determine their abilities and relate them to the world of professions.

Thus, we can talk about the existing contradiction between: the state of career guidance work in school and the scientific system of career guidance measures that ensure its quality, as well as the dynamic development of the modern 
labor market. It is noted that where career guidance work is carried out, it is mainly traditional in nature and is carried out in the form of scattered and haphazard events, which often boil down to the fact that information materials are distributed to future applicants and testing is carried out, determining the propensity of the student to a particular profession [4].

\section{LITERATURE REVIEW}

The works of L. I. Antsiferova, V. A. Bodrov, L. N. Kulikova, E. N. Shiyanov are devoted to the study of the issues of full-fledged mental and personal development of personality as the main condition of career guidance. In the works of M. R. Ginsburg, G. A. Kovalev, M. Yu.Savchenko, A. G. Spirkin, E. A. Yablokova the prerequisites for choosing a profession from the human inclinations point of view and abilities are revealed. Questions of formation of professional self-determination are considered by such Russian and foreign scientists as A. A. Bodaleva, I. S. Kohn, A. Maslow, R. S. Nemova, G. Allport, K. Rogers, etc. The analysis of scientific papers allows us to conclude that a wide range of issues remains insufficiently studied. There are unexplored aspects that allow to uniquely determine the effectiveness and efficiency of students professional orientation.

\section{RESEARCH METHODOLOGY}

A survey was used as a method of assessing the effectiveness of career guidance activities in the school. In February 2019, a survey of Mendeleev municipal district schoolchildren was conducted. The questionnaire included 20 questions.

In the presence of many negative opinions about the method of questioning, we believe that today it can be attributed to one of the main for the study self-determination of students, individuals when hiring them, studying, with its help, study any aspects of public relations.

\section{RESULTS}

During the study, 552 schoolchildren of Mendeleev municipal district of the Republic of Tatarstan or $25 \%$ of the total number of students in the district were interviewed. All 19 educational institutions of the district took part in the survey: $31.6 \%$ of them are urban schools, $68.4 \%$ are rural schools. Among the respondents, the gender distribution was almost equal: $47.0 \%$ - boys, $53.0 \%$ - girls. Age of respondents: from 14 to 17 years.

Almost every third Respondent (35.2\%) decided on a particular profession, $31.7 \%$ of students make a choice between several professions, $12.7 \%$ decided only on the type of training profile in an educational institution, $11.8 \%$ at the time of the survey could not answer the question: "Have you decided on your future profession?"

In the first place - a doctor, nurse, physician (14.1\%). In second place - a teacher $(13.0 \%)$, then a programmer $(8.6 \%)$. In this case, it should be noted that students could name several professions at the same time, with a very high spread between the competencies that must be possessed in a particular area, i.e. the student simultaneously chooses between a doctor and a programmer, an athlete and a mechanic.

Here are some, largely contradictory answers: doctor and programmer; medicine and photographer; nurse, doctor, fireman, oilman; welder, pathologist; programmer economist, lawyer, engineer, entrepreneur; welder, trucker; oilman, psychologist, doctor, cook; doctor, lawyer, freelancer; medicine, sports, prosecutor, lawyer, secretary, accountant, etc.

Only a few respondents make a choice between related professions, their choice is most likely determined by extracurricular detail, visiting circles:

* "Hockey player, hockey coach".

- "First I will become a hockey player, then a hockey coach."

- "Mounted police, the Ranger, the trainer on equestrian sport".

\section{* "Graphic designer, Illustrator".}

At the same time, there are cases when a student says that he made a choice of profession, and in the comments indicates the place of work or specialty at the University, i.e. these respondents choose the following professions: plant, ammonium, applied informatics, the ministry of internal affairs. Therefore, it is very important that the student tried himself in many areas: various circles, sports sections, visiting the centers of technical creativity, etc. [6, p. 495]. Only in this case, he will be able to see all advantages and disadvantages of each profession being tried.

To the question: "What influenced the choice of your profession?" the students gave the following answers. The majority of respondents said that they are interested in this "profession" (63.4\%). 44.4\% of respondents pointed to the opportunity to earn well. $34.3 \%$ of schoolchildren consulted their parents. $19.0 \%$ believe that they have a tendency to study this profession.

\section{DISCUSSION}

Career guidance in a modern school is a system of identifying students ' abilities and aptitudes for certain types of professional activity, as well as the formation of readiness for work and help in determining the future career. It is implemented directly during the educational process, as well as in extracurricular work with students $[7,8]$.

According to our President Vladimir Putin: "the choice of profession determines the future." This is evidenced by the Federal state standard of basic general education of the new generation, determining the need for career guidance. GEF defines "portrait of the primary school graduate " as someone who "focuses in the world of professions, understanding the importance of professional activities for a sustainable development of society and nature" [9].

According to a study conducted among parents and children of different ages, the main peak of parental anxiety falls on the period of a child growing up from 10 to 14 years. 
This is due to the fact that at this time the interest of children in the profession begins to grow. Adults begin to feel anxiety due to the lack of information about what professions will be in demand on the horizon of 10-15 years, and the lack of pronounced inclinations in the child. One in five parents admit that they can not help their child with the choice of profession, because they do not have enough information about the labor market of the present and future. The most paradoxical thing is that $60 \%$ of adolescents parents after 14 years see the need for earlier acquaintance of children with work and, perhaps, with the future profession-up to 10 years [10].

The right choice of life path brings great moral satisfaction, as a person gets the opportunity for greater selfrealization, because only in the favorite business he can achieve truly significant success. And besides, doing business, for which he was born, he can bring great benefit to people. However, this choice becomes impossible to make if the student does not have the slightest idea about what people do in a particular profession.

What is happening in reality. 30-35\% of students already on 2-3 courses realize about a wrong choice of a speciality, study not where would like. "A third of University students are ballast! And it is only those who openly admit that they made a mistake with the choice of profession..."- leads data Franz sheregi, director of the center for social forecasting, professor of the National research nuclear University MEPhI [11]. At the same time, a third of students drop out during training, a third of graduates radically change their profession. And among humanitarians such at all half of. Choosing a profession is a serious decision that must be made taking into account objective information about the conditions of admission and training and the prospects for further employment. As a result, the wrong choice of the student leaves the student with an unloved specialty and, as a consequence, with a useless diploma [13]. To help young professionals come refresher courses and professional retraining. Within five years after graduation, $60 \%$ of young professionals go for retraining or advanced training [14].

Currently, many organizations are engaged in career guidance work, meaning networking.

With this approach, there is interaction with the maximum possible number of links and the inclusion of any number of objects, work is carried out on a variety of uncoordinated projects. At the same time, the trained personnel has to work in the new information and educational space with the use of digital educational resources and distance education technologies that are represented in the University. Therefore, the higher education institution should assume the role of coordinator in choosing a professional life path by creating a career guidance laboratory. The university through the work of career guidance laboratory develops a model, a road map of human development.

Career guidance laboratory builds network interaction between all participants of the chain: school-collegeuniversity-employer, etc. in accordance with the request of the labor market, the university develops additional education programs for a specific category of people, which helps the institution to form its extra-budgetary fund, i.e. for the University - it is additional income.

\section{CONCLUSIONS}

In Russia, dozens of sociological studies are regularly conducted, the results of which reflect that school graduates have a poor understanding of their opportunities, requirements for the profession and the labor market. In connection with the current situation, a model of creating a career guidance laboratory is proposed, which unites all participants of the chain: school-college-university-employer, etc.:

1. The university should assume the role of career guidance coordinator by creating a career guidance laboratory for the following participants:

- $\quad$ students who pass the test for career guidance and in accordance with their preferences choose the exam, who chose the final exams in specialties suitable for the University, become their potential customers;

- students who through professional laboratories have the opportunity to choose the enterprise that interests them, within the framework of training at the University;

- working professionals who pass tests at the University and further educational institution helps the employee in overcoming the burnout crisis, growth (career ladder), change of activity.

2. The university develops programs of additional education for a specific category of people, replenishing its extra-budgetary fund, having additional income.

3. The university through the work of career guidance laboratory develops a model, a road map of human development.

\section{Acknowledgment}

The work is performed according to the Kazan Federal University Competitive Growth Russian Government Program.

\section{References}

[1] History of career guidance in Russia in infographics [Electronic resource]. $\quad-\quad$ Mode of access: https://proforientator.ru/publications/articles/istoriya-proforientatsii-vrossii-v-infografike.html (date accessed: 15.01.2019).

[2] Tracy Brian. Maximum Achievement Goal Planner. Success Library, 1995. 83 p.

[3] Tracy Brian. Speak to Win. Success Library, 2008. 208 p.

[4] Mukhametzyanova F. S. Cluster model of career guidance work with students / / Vocational education in Russia and abroad. 2016, 24-29.

[5] Navigator for parents on talent development in the Republic of Tatarstan [ Text] / edited by S. S. Gil, M. A. Sikorskaya-Dkanova-Kazan, 2015. $164 \mathrm{p}$.

[6] Safargaliev E. R. Method of evaluation of educational activity of teachers [Text] / E. R. Safargaliev. In the collection: Problem learning in the modern world VI international Mahmut readings: a collection of 
[10] How to survive the exam and choose a profession. Tips recruiters. [Electronic resource.] - Mode of access: https://mel.fm/blog/aidarfarrakhov/63752-kak-perezhit-yege-i-vybrat-professiyu-sovetyrekruterov (date accessed: 10.05.2019). A. Martynova. - 2016. - Pp. 494-498.

[7] Safargaliev E.; Nikolaeva A. Methodology for the educational activities of the university educational process [National academy of managerial staff of culture and arts herald]. 2017. no 2. pp. $218-221$.

[8] Safargaliev E., Eremina I., Savitsky S., Camelina V. Mathematical model and qualimetric assessment of graduate education quality in environment saturated with information and communication technologies [International Education Studies]. 2015. no 8. pp. 78 - 83.

[9] Order of the Ministry of education and science of the Russian Federation of December 17, $2010 \mathrm{~N} 1897$ "on approval of the Federal state educational standard of basic General education "[Electronic resource]. - Mode of access: https://xn--80abucjiibhv9a.xn--p1ai/documents/938 (date accessed: 19.08.2018).

[11] Konyukhova K. a Third of students study not where they want and not what they need / / Komsomolskaya Pravda. 2014 [Electronic resource] access Mode: https://www.nnov.kp.ru/daily/26300.5/3178190/ (accessed 17.06.2018).

[12] Lyubova O.V., Akhmadeeva O.A., Guzaleva S.Y., Zubkova S.V., Safargaliev E.R. Tenant satisfaction and its evaluation [Asian Social Science]. 2015. no 11. pp. 319 - 328.

[13] Alexsandr S. Kuznetsov. Russian Professor's meeting. Russian Journal of Physical Education and Sport. 2019, 14(1), pp. 17-22. DOI: 10.14526/2070-4798-2019-14-1-18-24

[14] Writer's Handbook. Mill Valley, CA: University Science, 1989. 